\section{Cancer Scenario in India}

\section{Neeraj Jain ${ }^{1 *}$, Sakshi Jain² and Abhimanyu Rakesh ${ }^{1}$ \\ ${ }^{1}$ Sri Guru Ram Das University of Health Sciences, Amritsar, India}

${ }^{2}$ Himachal Institute Of Dental Sciences, Paonta Sahib, Himachal Pradesh, India

\begin{abstract}
India is a developing country. The present population is 1.35 billion of which 1.4 million Populations are diagnosed with cancer every year. A total of 2.25 million cases are prevalent at a given time, mortality from cancer is as high as 1.2 million. Cervix and Breast are leading cancers among females and head neck and lung are leading cancers among males. Due to poverty and illiteracy there is lack of awareness which leads to presentation at advanced or metastatic stage. The treatment in most of cases is palliative. Though now the awareness about cancer has increased and urban population is very conscious about the disease (Figure 1).
\end{abstract}

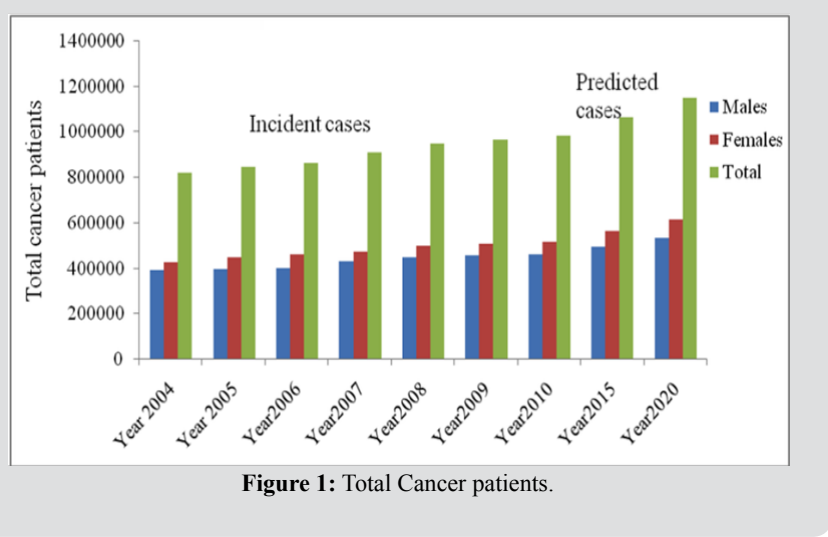

\section{Etiology}

The chemical, biological and other environmental identities are responsible for uncontrolled and unorganized proliferation of cells (carcinogens). Basically, under special circumstances carcinogens interact with DNA of the normal cells resulting into a series of complex multistep processes responsible for uncontrolled cell proliferation or tumors [1]. The causes for cancers can be both either internal

${ }^{*}$ Corresponding author: Neeraj Jain, Sri Guru Ram Das University of Health Sciences, Amritsar, India, Tel: +91 9814299045; E-mail: neer1967@yahoo.com

Citation: Jain N, Jain S, Rakesh A (2019) Cancer Scenario in India. J Genet Genomic Sci 4: 014

Received: August 10, 2019; Accepted: December 18, 2019; Published: December 25, 2019

Copyright: () 2019 Jain N, et al. This is an open-access article distributed under the terms of the Creative Commons Attribution License, which permits unrestricted use, distribution, and reproduction in any medium, provided the original author and source are credited. factors like inherited mutations, hormones, and immune conditions or environmental factors such as tobacco, diet, radiation and other infectious agents. In the developed and developing countries, radiations are also notorious carcinogens. The consumption of tobacco is the leading cause of cancers in India. Approximately $87 \%$ males and $85 \%$ females have been found to have lung cancer due to tobacco smoking in the form of bidi (a thin South Asian cigarette type structure filled with tobacco flake and wrapped in a tendu leaf, tied with a string at one end) and cigarette in India [2,3]. About $10 \%$ cancer occurrence is due to radiation effect, both ionizing and non-ionizing [4]. A significant variation of cancer has been reported due to life styles and food habits [5]. For example, Asians have 25 and 10 times lower incidences of prostate and breast cancers, respectively, as compared to Western countries which may be attributed to comparatively simple life styles adopted by Asians, and safe sexual practices. It is interesting to mention here that the rates of these cancer incidences increase substantially when Asians migrate to the Western countries; indicating a clear relationship of carcinogenesis with food habits and living styles. The various cancer causes have been compiled by visiting various hospitals, cancer agencies and institutes and plotted in figure 2. Some important causes of cancer in India are discussed in the following sub-sections briefly.

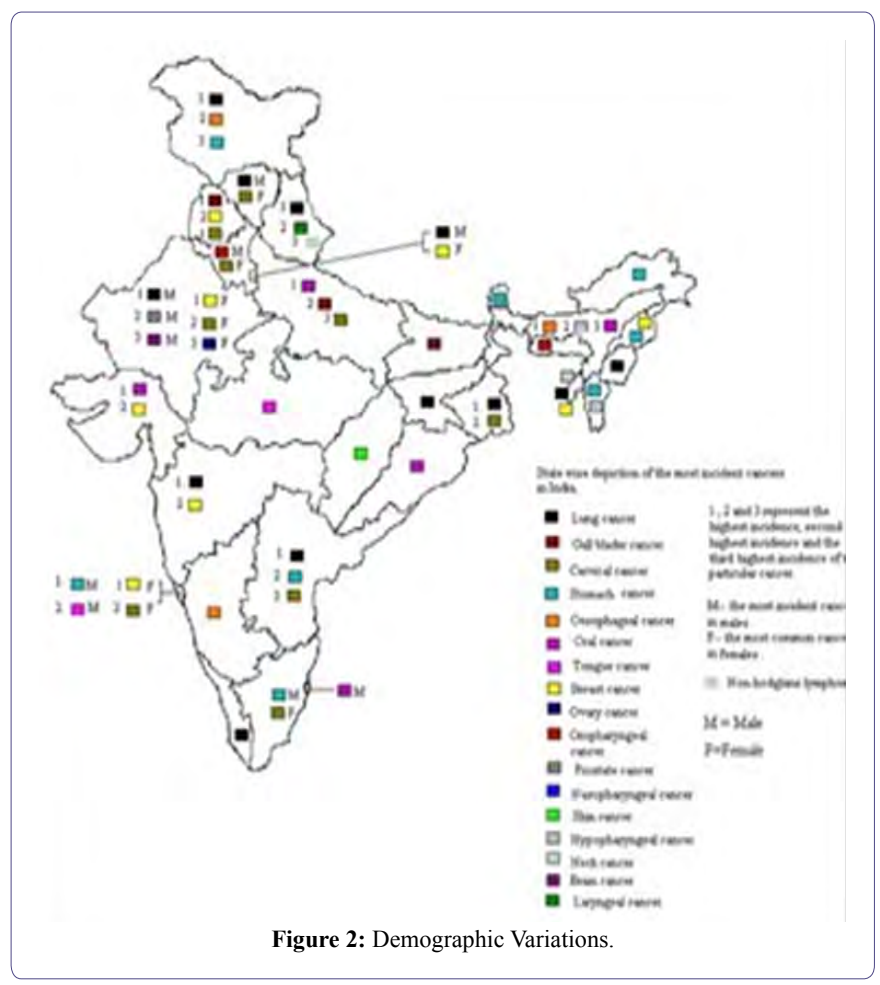

\section{Demographic Variations}

There is lot of financial, religious and demographic variations in the country. In 1960 more than $80 \%$ population were rural but now 
$60 \%$. Urbanization has lead to increased incidence of cancer. In North East region of the country cancer incidence is very high this is due to Tobacco and household burning of firewood. Incidence of Stomach cancer is high in South India due to diet rich in salt and spices. In Malwa region of Punjab incidence of Cancer Oesophagus, Gall Bladder, and Breast is high dueto high use of pesticides and diet rich in fats. In states of UP, Bihar, MP incidence of oral cancer is very high due to habit of tobacco chewing.

\section{Diagnostic Facilities}

- FNAC/ BIOPSY available at Urban Centers

- IHC available in Metro cities

- Radiologyavailable inSemi urban and urban areas

- PET CT available in Urban Centers only

\section{Treatment Facilities}

Treatment facilities are lacking due to overpopulation, there are only 3500 qualified Radiation Oncologists in 300 centres and there is shortage of 600 centers as per WHO criteria. There are 400 teletherapy machines out of which $50 \%$ are Cobalt units and shortage of 1200 units. Doctor Patient ratio is 1:2000 needs to be reduced to 1:1000. Medical oncologists are less than 2000 and confined to higher and corporate centres in Metro cities and beyond the reach of majority of population. Same scenario is of surgical oncologists and most of cancer surgeries are unplanned and done at peripheral centres by general surgeons. Radiation and Surgical oncologists also practice chemotherapy.

\section{Financial Constraints}

Financial constraints are other issue for a radical and effective treatment, only $5 \%$ population can afford treatment of their own and $50-60 \%$ can afford treatment with difficulty or with the help of insurances. Lack of health insurance leads to a financial burden on effected family and despite being in a curable stage the patient fails to get required treatment. Central and state governments have started funding programs for diagnosis and treatment but still therapies are beyond reach of majority people. More funds are being allocated under National Cancer Control Program with sole aim of early detection and cure. A 700 bedded National Cancer Institute has been established near New Delhi for research and treatment of cancer.Pharma companies are also running Patient Assistance Programs and costly medicines are given as free cycles after patient purchases initial cycles.

\section{References}

1. Carmaeia B (1993) Molecular mechanisms in cancer induction and Prevention. Environ Health Perspect 101: 237-245.

2. Behera D, Balamugesh T (2004) Lung Cancer in India. Indian J Chest Dis Allied Sci 46: 269-281.

3. Notani P, Sanghavi LD (1974) A retrospective study of lung cancer in Bombay. Br J Cancer 29: 477-482.

4. Belpomme D, Irigaray P, Hardell L, Clapp R, Montagnier L, et al. (2007) The multitude and diversity of environmental carcinogens. Environ Res 105: 414-429.

5. Helbock HJ, Beckman KB, Shigenaga MK, Walter PB, Woodall AA, et al. (1998) DNA oxidation matters: the HPLC-electrochemical detection assay of 8-oxo-deoxyguanosine and 8-oxo-guanine. Proc Nat Acad Sci USA 95: 288-293. 


\section{Hit \\ HERALD}

Journal of Anesthesia \& Clinical Care

Journal of Addiction \& Addictive Disorders

Advances in Microbiology Research

Advances in Industrial Biotechnology

Journal of Agronomy \& Agricultural Science

Journal of AIDS Clinical Research \& STDs

Journal of Alcoholism, Drug Abuse \& Substance Dependence

Journal of Allergy Disorders \& Therapy

Journal of Alternative, Complementary \& Integrative Medicine

Journal of Alzheimer's \& Neurodegenerative Diseases

Journal of Angiology \& Vascular Surgery

Journal of Animal Research \& Veterinary Science

Archives of Zoological Studies

Archives of Urology

Journal of Atmospheric \& Earth-Sciences

Journal of Aquaculture \& Fisheries

Journal of Biotech Research \& Biochemistry

Journal of Brain \& Neuroscience Research

Journal of Cancer Biology \& Treatment

Journal of Cardiology: Study \& Research

Journal of Cell Biology \& Cell Metabolism

Journal of Clinical Dermatology \& Therapy

Journal of Clinical Immunology \& Immunotherapy

Journal of Clinical Studies \& Medical Case Reports

Journal of Community Medicine \& Public Health Care

Current Trends: Medical \& Biological Engineering

Journal of Cytology \& Tissue Biology

Journal of Dentistry: Oral Health \& Cosmesis

Journal of Diabetes \& Metabolic Disorders

Journal of Dairy Research \& Technology

Journal of Emergency Medicine Trauma \& Surgical Care

Journal of Environmental Science: Current Research

Journal of Food Science \& Nutrition

Journal of Forensic, Legal \& Investigative Sciences

Journal of Gastroenterology \& Hepatology Research

Journal of Gerontology \& Geriatric Medicine

Journal of Genetics \& Genomic Sciences

Journal of Hematology, Blood Transfusion \& Disorders

Journal of Human Endocrinology

Journal of Hospice \& Palliative Medical Care

Journal of Internal Medicine \& Primary Healthcare

Journal of Infectious \& Non Infectious Diseases

Journal of Light \& Laser: Current Trends

Journal of Modern Chemical Sciences

Journal of Medicine: Study \& Research

Journal of Nanotechnology: Nanomedicine \& Nanobiotechnology

Journal of Neonatology \& Clinical Pediatrics

Journal of Nephrology \& Renal Therapy

Journal of Non Invasive Vascular Investigation

Journal of Nuclear Medicine, Radiology \& Radiation Therapy

Journal of Obesity \& Weight Loss

Journal of Orthopedic Research \& Physiotherapy

Journal of Otolaryngology, Head \& Neck Surgery

Journal of Protein Research \& Bioinformatics

Journal of Pathology Clinical \& Medical Research

Journal of Pharmacology, Pharmaceutics \& Pharmacovigilance

Journal of Physical Medicine, Rehabilitation \& Disabilities

Journal of Plant Science: Current Research

Journal of Psychiatry, Depression \& Anxiety

Journal of Pulmonary Medicine \& Respiratory Research

Journal of Practical \& Professional Nursing

Journal of Reproductive Medicine, Gynaecology \& Obstetrics

Journal of Stem Cells Research, Development \& Therapy

Journal of Surgery: Current Trends \& Innovations

Journal of Toxicology: Current Research

Journal of Translational Science and Research

Trends in Anatomy \& Physiology

Journal of Vaccines Research \& Vaccination

Journal of Virology \& Antivirals

Archives of Surgery and Surgical Education

Sports Medicine and Injury Care Journal

International Journal of Case Reports and Therapeutic Studies

Submit Your Manuscript: http://www.heraldopenaccess.us/Online-Submission.php 